\title{
Clinical Usefulness of Serum Uric Acid and Resting Heart Rate in the Diagnosis of Metabolic Syndrome in Korean Adults
}

\author{
Kyung-A Shin ${ }^{\dagger}$ \\ Department of Clinical Laboratory Science, Shinsung University, Chungnam 31801, Korea
}

\begin{abstract}
Elevated serum uric acid and resting heart rate are risk factors and predictors of metabolic syndrome. However, few studies have examined the optimal cutoff value for serum uric acid and resting heart rate to predict metabolic syndrome in Korean adults. Subjects for this study were 22,302 adults (average age 45 years old), who underwent health screening examination from January 2010 to December 2012 at the Health Promotion Center of one hospital in Gyeonggi-do for general health check-up. The uric acid and resting heart rate cutoff values were calculated by ROC analysis for metabolic syndrome. Elevated serum uric acid and resting heart rate were associated with an increased prevalence of metabolic syndrome in Korean adults. The optimal cutoff value for uric acid level to predict metabolic syndrome in adults was $4.95 \mathrm{mg} / \mathrm{dL}$ (male 6.35, female 4.55) and optimal cutoff value for resting heart rate to predict metabolic syndrome was 68 beats per minute (male 66, female 68). However, serum uric acid and resting heart rate were found to have limitations for the diagnosis of metabolic syndrome.
\end{abstract}

Key Words: Metabolic syndrome, Uric acid, Resting heart rate

\section{서 론}

요산은 크산틴(xanthine)이 크산틴 산화효소(xanthine oxidase) 또는 크산틴 탈수소효소(xanthine dehydrogenase) 의 활성화에 의해 생성되는 퓨린의 최종 대사산물로 통 풍과 신장결석의 위험요인으로 인식되고 있다(Feig et al., 2013). 그러나 역학연구를 통해 혈청 요산은 대사증후군, 만성 신장질환, 심장-뇌혈관질환과 관련이 있다고 보고된 다(Ioachimescu et al., 2008; Tamariz et al., 2011). 특히 최근 연구들은 요산이 대사증후군 위험인자일 뿐만 아니라 당 뇨병, 고혈압, 심혈관질환과 관련이 있다고 제시하고 있어 요산의 역할에 관심이 집중되고 있다(Tamariz et al., 2011;

Feig et al., 2013).

혈중 요산이 심혈관계에 작용하는 기전은 퓨린 대사과
정에서 요산과 함께 생성되는 산화효소(superoxidase)에 의 해 활성산소(reactive oxygen species, ROS)의 생성은 증가 하고, 산화질소(nitric oxide, NO)의 생성은 억제하여 혈관 저항성을 증가시켜 결국에는 혈관내피세포 기능장애를 초 래한다(Kanellis and Kang, 2005). 요산에 의한 혈관내피세포 기능장애는 대사증후군 발생에 핵심적인 역할을 하는 인 슐린저항성을 유발하는 기전으로 생각된다(Tomiyama et al., 2011). 고요산혈증은 고인슐린혈증 발병에 선행하여 나 타나며, 고인슐린혈증은 근위세뇨관에서 요산을 재흡수하 여 고요산혈증을 일으킨다(Feig et al., 2013; Li et al., 2013). 또한 혈청 요산은 혈소판 응집 및 부착을 유도하여 혈전 생성과 저밀도 지단백(low density lipoprotein, $\mathrm{LDL}$ ) 콜레스 테롤의 산화를 촉진함으로써 심혈관질환 발생에 영향을 미친다(Kanellis and Kang, 2005). Yoo 등(2004)은 혈청 요산 치가 정상범위에 속하더라도 혈청 요산 농도가 증가할수

* Received: March 12, 2017 / Revised: March 30, 2017 / Accepted: May 21, 2017

${ }^{\dagger}$ Corresponding author: Kyung-A Shin. Department of Clinical Laboratory Science, Shinsung University, 1 Daehak-Ro, Dangjin-Si, Chungnam 31801 , Korea. Tel: +82-41-350-1408, Fax:+82-41-350-1355, e-mail: mobitz2@shinsung.ac.kr

(C) The Korean Society for Biomedical Laboratory Sciences. All rights reserved.

(c) This is an Open Access article distributed under the terms of the Creative Commons Attribution Non-Commercial License (http://creativecommons.org/licenses/by-nc/3.0/) which permits unrestricted non-commercial use, distribution, and reproduction in any medium, provided the original work is properly cited. 
록 대사증후군 위험도가 비례적으로 증가함을 보고하였다.

안정시 심박수(resting heart rate)는 1 분 동안 심장이 수축 하여 혈액을 온몸으로 박출하는 횟수를 의미하며(Diaz et al., 2005), 굴심방결절 활동에 의해 결정되고 교감신경과 미주신경활성의 상호작용에 의해 영향을 받는다(Menown et al., 2013). 안정시 심박수 증가는 교감신경의 과활성과 미주신경 긴장도(vagal tone) 감소를 나타내는 징후이며 (Nanchen et al., 2013), 자율신경계 이상을 파악할 수 있는 중요한 지표이다(Palatini and Julius, 2004; Bemelmans et al., 2012; Johansen et al., 2013; Menown et al., 2013). 교감신경 활성 증가에 따른 안정시 심박수 증가는 인슐린저항성과 비만에 선행하여 나타날 수 있으며, 교감신경 활성화는 인 슐린저항성의 원인이자 결과로 보고된다(Bemelmans et al., 2012; Nanchen et al., 2013). 그러므로 대사증후군에서는 혈 압이 정상인 경우라도 교감신경계가 항진되고, 자율신경 계 조절능력이 저하되어 심박수가 증가하는 경향을 보인 다(Lauer et al., 1996).

한편, 혈중 요산 농도 및 안정시 심박수의 감소가 심혈 관계질환과 대사증후군 위험을 예방하는 것으로 보고되고 있으나(Liu et al., 2016), 대사증후군 진단을 위한 요산과 안정시 심박수의 적정 절단값 설정(cut-off level)에 대한 연구는 매우 제한적이다. 이에 본 연구에서는 ROC curve 를 이용해 한국 성인의 대사증후군 진단을 위한 요산과 안정시 심박수의 최적 절단값을 설정하고, 대사증후군 진 단의 유용성에 대해 알아보고자 하였다.

\section{재료 및 방법}

\section{실험 대상자 및 대사증후군 진단}

본 연구 대상자는 2010년 1월부터 2012년 12월까지 경 기지역 일개 종합병원에서 건강검진을 시행한 20세 이상 의 성인남녀를 대상으로 하였다. 전체 대상자 총 23,356 명 중 과거력으로 당뇨병과 고혈압 진단을 받은 환자, 심박 수에 영향을 미치는 베타차단제를 복용하는 환자와 결 측치를 포함하는 1,054 명을 제외한 최종 대상자는 남성 13,652 명, 여성 8,650 명으로 총 22,302 명 이었다. 과거력 및 복용하는 약물에 대해서는 자기기입식 문진표를 통해 조사하였으며, 본 연구는 경기지역 종합병원 기관생명윤 리위원회의 승인을 받아 시행하였다(IRB No: D-1205008-2461). 대사증후군 진단기준은 AHA/NHLBI (American Heart Association/National Heart, Lung, and Blood Institute, 2005)의 기준에 따라 복부비만, 혈압 상승, 혈당 상승,
중성지방 상승, $\mathrm{HDL}$-콜레스테롤 감소의 5 가지 위험요인 중 3 가지 이상 만족할 경우 대사증후군으로 정의하였다 (Grundy et al., 2005). 그 중 혈압 상승은 수축기 혈압이 $130 \mathrm{mmHg}$ 이상 또는 이완기 혈압이 $85 \mathrm{mmHg}$ 이상인 경우, 혈당 상승은 공복혈당이 $100 \mathrm{mg} / \mathrm{dL}$ 이상인 경우로 하였다. 중성지방 상승은 혈중 중성지방이 $150 \mathrm{mg} / \mathrm{dL}$ 이 상, HDL (high density lipoprotein)-콜레스테롤 감소는 혈중 $\mathrm{HDL}$-콜레스테롤이 남성 $40 \mathrm{mg} / \mathrm{dL}$ 미만, 여성 $50 \mathrm{mg} / \mathrm{dL}$ 미만으로 하였다. 복부비만은 AHA/NHLBI 기준으로 남성 $102 \mathrm{~cm}$ 이상, 여성 $88 \mathrm{~cm}$ 이상으로 정의하고 있으나, 본 연구에서는 동양인의 복부비만 기준에 적합한 세계보건 기구 서태평양 지역 International Obesity Task Force에서 제 시하는 남성 $90 \mathrm{~cm}$ 이상, 여성 $80 \mathrm{~cm}$ 이상을 복부비만으 로 정의하였다(WHO, 2000).

\section{신체계측 및 안정시 심박수 측정}

신장과 체중은 DS-103M (Jenix, Seoul, Korea) 자동 신체 계측기를 이용하여 측정하였으며, 체질량지수(body mass index, BMI)는 몸무게 $(\mathrm{kg})$ 를 키 $(\mathrm{m})$ 의 제곱으로 나눈 식으 로 추정하였다. 허리둘레는 양 발을 $25 \sim 30 \mathrm{~cm}$ 벌리고 바 로 선 자세에서 갈비뼈 최하단부위와 골반 엉덩뼈능선 최 상단부위의 중간 지점을 측정하였으며, 엉덩이 둘레는 줄 자로 엉덩이의 가장 돌출부위를 지나 수평이 되도록 하여 측정하였다. 수축기와 이완기 혈압은 10 분 이상 휴식을 취 한 후 앉은 자세에서 수은 혈압계로 측정하였다. 안정시 심박수는 표준 12유도 자동 심전계(Cardiocare 2000, Bionet, Korea)로 안정시 심전도를 기록한 후 심전도 상에 기록된 심박수를 안정시 심박수로 설정하였다.

\section{혈액검사}

혈액검사는 8시간 이상 공복상태로 위팔정맥(antecubital vein)에서 채혈하였으며, TBA-200FR NEO (Toshiba, Tokyo, Japan) 생화학 자동분석기로 공복혈당, 중성지방, 총콜레 스테롤, HDL-콜레스테롤, $\mathrm{LDL}$-콜레스테롤, 요산, 고감도 $\mathrm{C}$-반응단백질(high sensitivity C-reactive protein, hs-CRP)을 측정하였다. 당화혈색소(hemoglobin A1c, HbA1c)는 EDTA 전혈 검체로 Variant II (Bio Rad, CA, USA)를 이용하여 고성 능액체크로마토그래피법(high performance liquid chromatography, HPLC)으로 측정하였다. 인슐린은 Modular Analytics E170 (Roche, Mannheim, Germany) 장비로 전기화학발광면 역분석법(electrochemiluminescence immunoassay, ECLIA)의 원리로 검사하였으며, 인슐린저항성 평가 지표인 HOMA- 
IR (homeostasis model assessment-insulin resistance)은 공복 혈당과 인슐린 농도를 이용하여 [공복시 인슐린 $(\mu \mathrm{IU} / \mathrm{mL})$ $\times$ 공복시 혈당 $(\mathrm{mg} / \mathrm{dL})] / 405$ 의 계산식으로 평가하였다 (Moon et al., 2010).

\section{자료처리방법}

본 연구의 통계학적 분석은 SPSS Windows 21.0 (IBM, Armonk, USA) 프로그램을 이용하였으며, 대상자들은 혈 청 요산치와 안정시 심박수에 따라 4 등분하여 네 군으로 분류하였다. 혈청 요산치 사분위수와 안정시 심박수 사분 위수에 따른 대사증후군 위험요인의 차이를 비교하기 위 하여 일원배치 분산분석(one way ANOVA)을 실시하였으며, 차이가 있는 경우 사후검증은 Bonferroni를 적용하였다. 또 한 혈청 요산치 사분위수와 안정시 심박수 사분위수간의 성별 및 혈압 상승, 혈당 상승, 중성지방 상승, $\mathrm{HDL}$-콜레 스테롤 감소의 5 가지 대사증후군 위험요인의 유병률을 비교하기 위해 카이제곱 검정(chi-square test)을 실시하였 다. 혈청 요산치와 안정시 심박수 사분위수에 따른 대사 증후군 교차비를 구하기 위해 로지스틱 회귀분석(logistic regression)을 시행하였으며, 오즈비(odds ratio, OR)와 95\% 신뢰구간(confidence interval, CI)을 제시하였다. 또한 로지 스틱 회귀분석시 연령과 성별이 요산치와 안정시 심박수 에 미치는 영향을 배제하기 위해 관심독립변수와 함께 연 령과 성별을 동시에 독립변수로 고려하여 통제한 후 분석 하였다. 요산치와 안정시 심박수가 대사증후군 진단을 위 한 정확한 지표인지를 알아보기 위해 ROC 곡선(Receiver Operating Characteristic Curve)의 면적을 비교하였다. 면적 은 0 과 1 사이의 값을 가지며, 0.5 에 가까울수록 예측력이 없고 1 이면 완벽하게 예측하는 것으로 분류하였다. 대사 증후군을 진단하기 위한 혈청 요산치와 안정시 심박수의 최적 절단값(optimum cut-off values)을 판단하기 위해 민 감도(sensitivity)와 특이도(specificity)의 합이 최대가 되는 지점을 혈청 요산치와 안정시 심박수의 적정 절단값으로 채택하였다. 본 연구의 통계학적으로 유의한 판정기준은 $P<0.05$ 로 설정하였다.

\section{결 과}

\section{요산의 사분위수에 따른 대상자의 의학적 특성}

혈청 요산치를 사분위수로 나누어 인체측정학 및 의학 적 지표의 차이를 비교한 결과는 Table 1 과 같다. 연령은 집단간 차이를 보였다 $(P<0.001)$. 인체측정학적 변인 중 신
장, 체중, 체질량지수, 허리둘레, 엉덩이 둘레는 1 사분위 수보다 2 사분위수가 높았으며, 1 사분위수와 2 사분위수보 다 3 사분위수가 높았다. 또한 4 사분위수는 1 사분위수, 2 사 분위수, 3 사분위수보다 높게 나타났다(각각 $P<0.001)$. 수 축기와 이완기 혈압은 1 사분위수보다 2 사분위수가 높았 으며, 1 사분위수와 2 사분위수보다 3 사분위수가 높았다. 또 한 4사분위수는 1 사분위수, 2 사분위수, 3 사분위수보다 높 게 나타났다 (각각 $P<0.001)$. 총콜레스테롤, $\mathrm{LDL}$-콜레스테 롤, 중성지방, 인슐린, 요산은 1 사분위수보다 2 사분위수가 높았으며, 1 사분위수와 2 사분위수보다 3 사분위수가 높았 다. 또한 1 사분위수, 2 사분위수, 3 사분위수보다 4 사분위 수가 높게 나타났다(각각 $P<0.001)$. 안정시 심박수는 4사 분위수에서 1 사분위수, 2 사분위수, 3 사분위수보다 높게 나 타났다 $(P<0.001)$. hs-CRP와 HOMA-IR은 1 사분위수보다 3 사분위수가 높았으며, 4 사분위수는 1 사분위수와 2 사분 위수보다 높았다(각각 $P<0.001)$. 공복혈당은 1사분위수보 다 2 사분위수, 3 사분위수, 4 사분위수에서 높았다 $(P<0.001)$. $\mathrm{HbA1c}$ 는 1 사분위수보다 2사분위수와 3 사분위수가 높았 으며, 2 사분위수와 3 사분위수보다 4사분위수가 높았다 $(P<0.001)$. 그러나 $\mathrm{HDL}$-콜레스테롤은 1 사분위수보다 2사 분위수, 3 사분위수, 4 사분위수가 낮았으며, 3 사분위수는 1 사분위수와 2 사분위수보다 낮았다. 또한 4 사분위수는 1 사분위수, 2 사분위수, 3 사분위수보다 낮게 나타났다 $(P<$ 0.001). 대사증후군 유병률 및 대사증후군 위험요인은 집 단간 차이를 보였으며, 혈압 상승, 혈당 상승, 중성지방 상 승, 복부비만 및 대사증후군 유병률은 요산의 분위수가 높아질수록 유병률 빈도가 높게 나타났다(각각 $P<0.001)$.

\section{안정시 심박수의 사분위수에 따른 대상자의 의학적 특성}

안정시 심박수를 사분위수로 나누어 인체측정학 및 의 학적 지표의 차이를 비교한 결과는 Table 2와 같다. 연령 은 집단간 차이를 보였다 $(P<0.001)$. 체중은 1 사분위수, 2 사분위수, 3 사분위수보다 4 사분위수에서 높게 나타났다 $(P<0.001)$. 체질량지수는 1 사분위수보다 3 사분위수, 4 사분 위수가 높았으며, 4 사분위수는 2 사분위수, 3 사분위수보다 높았다 $(P<0.001)$ 허리둘레와 엉덩이 둘레, 수축기 혈압, 총콜레스테롤, 공복혈당, $\mathrm{HbA1c}$ 는 1 사분위수보다 2 사분위 수와 3 사분위수, 4 사분위수가 높았으며, 4 사분위수는 2 사 분위수, 3 사분위수보다 높게 나타났다(각각 $P<0.001)$. 이 완기 혈압, 안정시 심박수, 중성지방, 인슐린은 1 사분위수 보다 2 사분위수, 3 사분위수, 4 사분위수가 높았으며, 2 사분 위수보다 3 사분위수, 4 사분위수가 높았다. 또한 4 사분위 
Table 1. The variables characteristics of the different uric acid quartiles

\begin{tabular}{|c|c|c|c|c|c|}
\hline \multirow[b]{2}{*}{ Variables } & \multicolumn{4}{|c|}{ Uric acid levels quartiles $(\mathrm{n}=22,302)$} & \multirow[b]{2}{*}{$P$-value } \\
\hline & $\begin{array}{l}\text { Quartile } 1 \\
\leq 4.19\end{array}$ & $\begin{array}{l}\text { Quartile } 2 \\
4.20 \sim 5.29\end{array}$ & $\begin{array}{c}\text { Quartile } 3 \\
5.30 \sim 6.29\end{array}$ & $\begin{array}{l}\text { Quartile } 4 \\
\geq 6.30\end{array}$ & \\
\hline No. of subjects & 5,208 & 5,838 & 5,361 & 5,895 & \\
\hline Male $(\%)^{*}$ & $854(16.4)$ & $2,659(45.4)$ & $4,471(83.4)$ & $5,668(96.1)$ & $<0.001$ \\
\hline Age (year) & $45.43 \pm 11.40$ & $46.42 \pm 11.72^{*}$ & $45.62 \pm 11.16^{\dagger}$ & $44.07 \pm 10.55^{* \dagger *}$ & $<0.001$ \\
\hline Height (cm) & $160.78 \pm 7.30$ & $164.06 \pm 8.53^{*}$ & $169.35 \pm 7.93^{* \dagger}$ & $171.46 \pm 6.90^{*+*}$ & $<0.001$ \\
\hline Weight (kg) & $57.63 \pm 9.27$ & $62.83 \pm 10.82^{*}$ & $69.81 \pm 10.63^{* \dagger}$ & $74.54 \pm 10.70^{*+*}$ & $<0.001$ \\
\hline Body mass index $\left(\mathrm{kg} / \mathrm{m}^{2}\right)$ & $22.29 \pm 3.17$ & $23.39 \pm 6.07^{*}$ & $24.41 \pm 5.86^{* \dagger}$ & $25.35 \pm 4.08^{*+\frac{1}{i+}}$ & $<0.001$ \\
\hline Waist circumference (cm) & $73.31 \pm 8.38$ & $77.42 \pm 8.91^{*}$ & $81.89 \pm 8.24^{* \dagger}$ & $84.93 \pm 7.60^{* \dagger+}$ & $<0.001$ \\
\hline Hip circumference (cm) & $90.85 \pm 5.40$ & $92.40 \pm 5.56^{*}$ & $94.46 \pm 5.63^{* \dagger}$ & $96.05 \pm 5.64^{*} \uparrow$ & $<0.001$ \\
\hline Systolic blood pressure (mmHg) & $104.81 \pm 14.30$ & $108.01 \pm 14.24^{*}$ & $111.50 \pm 13.37^{* \dagger}$ & $113.26 \pm 12.89^{* *}$ & $<0.001$ \\
\hline Diastolic blood pressure (mmHg) & $66.87 \pm 9.81$ & $69.24 \pm 10.12^{*}$ & $72.20 \pm 9.95^{* \dagger}$ & $73.49 \pm 10.09^{*+*}$ & $<0.001$ \\
\hline Resting heart rate (bpm) & $63.29 \pm 8.70$ & $63.12 \pm 9.34$ & $63.31 \pm 9.33$ & $63.98 \pm 9.51^{* \uparrow+}$ & $<0.001$ \\
\hline Total cholesterol (mg/dL) & $185.28 \pm 32.12$ & $191.19 \pm 33.36^{*}$ & $194.26 \pm 33.79^{* \dagger}$ & $200.43 \pm 34.77^{* \dagger+}$ & $<0.001$ \\
\hline HDL-cholesterol (mg/dL) & $62.10 \pm 13.88$ & $58.28 \pm 13.96^{*}$ & $53.39 \pm 12.57^{* \dagger}$ & $50.75 \pm 11.60^{* * *}$ & $<0.001$ \\
\hline LDL-cholesterol (mg/dL) & $109.50 \pm 29.13$ & $116.40 \pm 30.41^{*}$ & $121.06 \pm 30.41^{* \dagger}$ & $126.36 \pm 31.32^{* \dagger *}$ & $<0.001$ \\
\hline Triglyceride (mg/dL) & $87.89 \pm 53.23$ & $107.96 \pm 68.86^{*}$ & $132.77 \pm 86.46^{* \dagger}$ & $162.19 \pm 104.93^{*+*}$ & $<0.001$ \\
\hline Fasting glucose (mg/dL) & $89.23 \pm 20.91$ & $90.28 \pm 19.28^{*}$ & $91.01 \pm 17.66^{*}$ & $90.57 \pm 15.34^{*}$ & $<0.001$ \\
\hline hs-CRP (mg/dL) & $0.13 \pm 0.51$ & $0.15 \pm 0.41$ & $0.16 \pm 0.37^{*}$ & $0.17 \pm 0.36^{* \dagger}$ & $<0.001$ \\
\hline HbAlc (\%) & $5.57 \pm 0.83$ & $5.62 \pm 0.75^{*}$ & $5.61 \pm 0.67^{*}$ & $5.56 \pm 0.55^{\dagger}$ & $<0.001$ \\
\hline Insulin $(\mu \mathrm{U} / \mathrm{mL})$ & $4.19 \pm 2.52$ & $4.69 \pm 3.05^{*}$ & $5.14 \pm 3.07^{* \dagger}$ & $5.75 \pm 3.46^{* \dagger+}$ & $<0.001$ \\
\hline HOMA-IR & $0.20 \pm 0.53$ & $0.21 \pm 0.58$ & $0.24 \pm 0.60^{*}$ & $0.25 \pm 0.63^{* \dagger}$ & $<0.001$ \\
\hline Uric acid (mg/dL) & $3.50 \pm 0.50$ & $4.69 \pm 0.32^{*}$ & $5.74 \pm 0.28^{* \dagger}$ & $7.23 \pm 0.85^{* \dagger}$ & $<0.001$ \\
\hline Metabolic Syndrome $(\%)^{\S}$ & $258(5.0)$ & $488(8.4)$ & $578(10.8)$ & $840(14.2)$ & $<0.001$ \\
\hline High blood pressure $(\%)^{\S}$ & $466(8.9)$ & $697(11.9)$ & $834(15.6)$ & $1,064(18.0)$ & $<0.001$ \\
\hline Low HDL-cholesterol $(\%)^{\S}$ & $721(13.8)$ & $899(15.4)$ & $774(14.4)$ & $968(16.4)$ & 0.001 \\
\hline High fasting glucose $(\%)^{\S}$ & $540(10.4)$ & $831(14.2)$ & $855(15.9)$ & $930(15.8)$ & $<0.001$ \\
\hline High triglyceride $(\%)^{\S}$ & $543(10.4)$ & $1,094(18.7)$ & $1,625(30.3)$ & $2,563(43.5)$ & $<0.001$ \\
\hline Abdominal obesity $(\%)^{\S}$ & $777(14.9)$ & $1,070(18.3)$ & $1,129(21.1)$ & $1,544(26.2)$ & $<0.001$ \\
\hline
\end{tabular}

Calculated by one way ANOVA and Bonferroni test.

Values are presented as mean \pm SD.

§. Calculated by $\chi^{2}$-test. Data are presented as number (\%).

Abbreviations: HDL, high density lipoprotein; LDL, low density lipoprotein; hs-CRP, high sensitivity C-reactive protein; HbA1c, hemoglobin A1c; HOMA-IR, homeostasis model assessment-insulin resistance.

*; Significantly different from Quartile 1 at $P<0.05,{ }^{\dagger}$; Significantly different from Quartile 2 at $P<0.05,{ }^{\star}$; Significantly different from Quartile 3 at $P<0.05$.

수는 3 사분위수보다 높게 나타났다(각각 $P<0.001)$. LDL콜레스테롤은 1 사분위수보다 2 사분위수, 3 사분위수, 4 사 분위수가 높았으며, 4 사분위수는 3 사분위수보다 높았다 $(P<0.001) . \mathrm{HDL}$-콜레스테롤은 1 사분위수보다 2 사분위수, 3 사분위수, 4 사분위수가 낮았으며, 4 사분위수는 2 사분위수, 3 사분위수보다 낮았다 $(P<0.001)$. hs-CRP는 1사분위수, 2 사
분위수보다 3 사분위수, 4 사분위수가 높았으며, 4 사분위수 는 3 사분위수보다 높았다 $(P<0.001)$. HOMA-IR은 1 사분 위수보다 2 사분위수, 4 사분위수가 높았으며, 4 사분위수는 2 사분위수, 3 사분위수보다 높았다 $(P<0.001)$. 대사증후군 유병률 및 대사증후군 위험요인은 집단간 차이를 보였으 며, 혈압 상승, 혈당 상승 및 대사증후군 유병률은 안정시 
Table 2. The variables characteristics of the different heart rate quartiles

\begin{tabular}{|c|c|c|c|c|c|}
\hline \multirow[b]{2}{*}{ Variables } & \multicolumn{4}{|c|}{ Heart rate levels quartiles $(n=22,302)$} & \multirow[b]{2}{*}{$P$-value } \\
\hline & $\begin{array}{c}\text { Quartile } 1 \\
\leq 56.9\end{array}$ & $\begin{array}{c}\text { Quartile } 2 \\
57.0 \sim 62.9\end{array}$ & $\begin{array}{c}\text { Quartile } 3 \\
63.0 \sim 67.9\end{array}$ & $\begin{array}{l}\text { Quartile } 4 \\
\geq 68.0\end{array}$ & \\
\hline No. of subjects & 4,996 & 6,146 & 6,304 & 4,856 & \\
\hline Male $(\%)^{*}$ & $3,220(64.5)$ & $3,726(60.6)$ & $3,685(58.8)$ & $3,021(62.6)$ & $<0.001$ \\
\hline Age (year) & $46.55 \pm 11.32$ & $45.74 \pm 11.16^{*}$ & $44.64 \pm 0.99^{* \dagger}$ & $44.66 \pm 11.46^{* \dagger}$ & $<0.001$ \\
\hline Height (cm) & $166.79 \pm 8.63$ & $166.61 \pm 8.83$ & $166.24 \pm 8.80^{*}$ & $166.49 \pm 8.77$ & 0.008 \\
\hline Weight (kg) & $65.87 \pm 11.35$ & $66.27 \pm 12.13$ & $66.16 \pm 12.37$ & $67.36 \pm 13.01^{*+*}$ & $<0.001$ \\
\hline Body mass index $\left(\mathrm{kg} / \mathrm{m}^{2}\right)$ & $23.63 \pm 4.37$ & $23.83 \pm 5.15$ & $23.91 \pm 5.87^{*}$ & $24.23 \pm 4.58^{*+\ddagger}$ & $<0.001$ \\
\hline Waist circumference $(\mathrm{cm})$ & $78.74 \pm 8.83$ & $79.30 \pm 9.18^{*}$ & $79.39 \pm 9.47^{*}$ & $80.77 \pm 9.94^{* \dagger}$ & $<0.001$ \\
\hline Hip circumference (cm) & $93.04 \pm 5.62$ & $93.41 \pm 5.70^{*}$ & $93.39 \pm 5.89^{*}$ & $94.06 \pm 6.37^{* \dagger *}$ & $<0.001$ \\
\hline Systolic blood pressure (mmHg) & $107.49 \pm 13.54$ & $108.67 \pm 13.53^{*}$ & $109.31 \pm 14.04^{*}$ & $112.80 \pm 14.77^{* \dagger+}$ & $<0.001$ \\
\hline Diastolic blood pressure (mmHg) & $68.98 \pm 9.87$ & $69.94 \pm 10.00^{*}$ & $70.54 \pm 10.27^{* \dagger}$ & $72.83 \pm 10.85^{* * *}$ & $<0.001$ \\
\hline Resting heart rate (bpm) & $52.44 \pm 3.30$ & $59.58 \pm 1.68^{*}$ & $65.73 \pm 1.98^{* \dagger}$ & $76.64 \pm 6.94^{* \dagger}$ & $<0.001$ \\
\hline Total cholesterol (mg/dL) & $190.75 \pm 32.66$ & $192.81 \pm 33.94^{*}$ & $193.24 \pm 33.47^{*}$ & $195.20 \pm 35.90^{*+\hbar}$ & $<0.001$ \\
\hline HDL-cholesterol (mg/dL) & $57.07 \pm 14.03$ & $56.14 \pm 13.72^{*}$ & $56.04 \pm 13.60^{*}$ & $54.70 \pm 13.48^{*+\ddagger}$ & $<0.001$ \\
\hline LDL-cholesterol (mg/dL) & $116.80 \pm 29.83$ & $118.61 \pm 31.02^{*}$ & $118.53 \pm 30.69^{*}$ & $120.14 \pm 32.33^{* *}$ & $<0.001$ \\
\hline Triglyceride (mg/dL) & $109.81 \pm 73.29$ & $121.05 \pm 80.97^{*}$ & $125.55 \pm 87.46^{* \dagger}$ & $138.37 \pm 98.82^{* \dagger \ddagger}$ & $<0.001$ \\
\hline Fasting glucose (mg/dL) & $87.44 \pm 12.92$ & $89.22 \pm 15.89^{*}$ & $89.89 \pm 17.30^{*}$ & $95.07 \pm 25.19^{* *}$ & $<0.001$ \\
\hline hs-CRP (mg/dL) & $0.12 \pm 0.29$ & $0.13 \pm 0.31$ & $0.15 \pm 0.37^{* \dagger}$ & $0.22 \pm 0.63^{* \dagger \dagger}$ & $<0.001$ \\
\hline HbAlc (\%) & $5.52 \pm 0.51$ & $5.56 \pm 0.61^{*}$ & $5.58 \pm 0.69^{*}$ & $5.72 \pm 0.93^{*+\uparrow}$ & $<0.001$ \\
\hline Insulin $(\mu \mathrm{U} / \mathrm{mL})$ & $3.98 \pm 2.49$ & $4.59 \pm 2.82^{*}$ & $5.04 \pm 2.96^{* \dagger}$ & $5.96 \pm 3.62^{* \dagger \ddagger}$ & $<0.001$ \\
\hline HOMA-IR & $0.16 \pm 0.48$ & $0.26 \pm 0.59^{*}$ & $0.15 \pm 0.52^{\dagger}$ & $0.35 \pm 0.72^{* \uparrow \uparrow}$ & $<0.001$ \\
\hline Uric acid (mg/dL) & $5.32 \pm 1.41$ & $5.29 \pm 1.46$ & $5.31 \pm 1.50$ & $5.44 \pm 1.52^{* \dagger}$ & $<0.001$ \\
\hline Metabolic Syndrome $(\%)^{\S}$ & $289(5.8)$ & $526(8.6)$ & $582(9.2)$ & $767(15.8)$ & $<0.001$ \\
\hline High blood pressure $(\%)^{\S}$ & $507(10.1)$ & $734(11.9)$ & $839(13.3)$ & $981(20.2)$ & $<0.001$ \\
\hline Low HDL-cholesterol $(\%)^{\S}$ & $617(12.3)$ & $949(15.4)$ & $955(15.1)$ & $841(17.3)$ & $<0.001$ \\
\hline High fasting glucose $(\%)^{\S}$ & $511(10.2)$ & $752(12.2)$ & $803(12.7)$ & $1090(22.4)$ & $<0.001$ \\
\hline High triglyceride $(\%)^{\S}$ & $988(19.8)$ & $1,538(25.0)$ & $1,712(27.2)$ & $1,587(32.7)$ & $<0.001$ \\
\hline Abdominal obesity $(\%)^{\S}$ & $780(15.6)$ & $1,187(19.3)$ & $1,297(20.6)$ & $1,256(25.9)$ & $<0.001$ \\
\hline
\end{tabular}

Calculated by one way ANOVA and Bonferroni test.

Values are presented as mean \pm SD.

§. Calculated by $\chi^{2}$-test. Data are presented as number (\%).

Abbreviations: HDL, high density lipoprotein; LDL, low density lipoprotein; hs-CRP, high sensitivity C-reactive protein; HbA1c, hemoglobin A1c; HOMA-IR, homeostasis model assessment-insulin resistance.

*; Significantly different from Quartile 1 at $P<0.05,{ }^{\dagger}$; Significantly different from Quartile 2 at $P<0.05,{ }^{\star}$; Significantly different from Quartile 3 at $P<0.05$.

심박수 분위수가 높아질수록 유병률 빈도가 높게 나타났 다(각각 $P<0.001)$.

\section{요산과 안정시 심박수 사분위수에 따른 대사증후군과의 관련성}

로지스틱 회귀분석을 통해 요산, 안정시 심박수의 사분
위수에 따른 대사증후군과의 관련성을 분석한 결과 Table 3 과 같다. 요산은 1 사분위수에 비해 2 사분위수에서 대사 증후군 발생이 1.7배 높았으며(odds ratio, OR: 1.680, 95\% confidence interval, 95\% CI: 1.428 1.976), 3사분위수는 2.3 배 높았다(OR: 2.311, 95\% CI: 1.943 2.749). 또한 4사분위 수는 1사분위수보다 대사증후군 발생 위험도가 3.4 배 높 
Table 3. Independent association between uric acid, resting heart rate and metabolic syndrome

\begin{tabular}{lccc}
\hline \hline & & Odds ratio (95\% confidence interval) & \\
fariables & & 1 & $P$ \\
& Quartile 1 & $1.680(1.428 \sim 1.976)$ & $<0.001$ \\
Uric acid (mg/dL) & Quartile 2 & $2.311(1.943 \sim 2.749)$ & $<0.001$ \\
& Quartile 3 & $3.426(2.875 \sim 4.083)$ & $<0.001$ \\
\hline \multirow{2}{*}{ Resting heart rate (bpm) } & Quartile 4 & 1 & $<0.001$ \\
& Quartile 1 & $1.636(1.406 \sim 1.904)$ & $<0.001$ \\
& Quartile 2 & $1.877(1.617 \sim 2.180)$ & $<0.001$ \\
\hline
\end{tabular}

Calculated by logistic regression adjusted for gender and age.

Values are presented as odds ratio ( $95 \%$ confidence interval).

Table 4. ROC-curve analysis according to uric acid and resting heart rate

\begin{tabular}{llcccc}
\hline \hline \multicolumn{1}{c}{ Variables } & & Cutoff value & Sensitivity & Specificity & AUC (95\% confidence interval) \\
\hline \multirow{2}{*}{ Uric acid (mg/dL) } & Total & 4.95 & $73.0 \%$ & $44.3 \%$ & $0.620(0.607 \sim 0.632)$ \\
& Male & 6.35 & $47.7 \%$ & $62.5 \%$ & $0.564(0.548 \sim 0.579)$ \\
& Female & 4.55 & $57.1 \%$ & $69.2 \%$ & $0.676(0.652 \sim 0.699)$ \\
\hline \multirow{3}{*}{ Resting heart rate (bpm) } & Total & 67.50 & $42.7 \%$ & $73.0 \%$ & $0.609(0.597 \sim 0.622)$ \\
& Male & 65.50 & $50.1 \%$ & $66.2 \%$ & $0.615(0.600 \sim 0.630)$ \\
& Female & 67.50 & $42.9 \%$ & $72.6 \%$ & $0.601(0.577 \sim 0.625)$ \\
\hline
\end{tabular}

Abbreviations: AUC, area under the curve.

은 양상을 보였다(OR: $3.426,95 \%$ CI: 2.875 4.083). 안정시 심박수는 1 사분위수보다 2사분위수에서 대사증후군 발생 이 1.7배 높았으며(OR: 1.636, 95\% CI: 1.406 1.904), 3사분 위수는 1.9 배 높았다(OR: $1.877,95 \%$ CI: 1.617 2.180). 또 한 4분위수는 1 사분위수보다 대사증후군 발생 위험도가 3.4배 높게 나타났다(OR: 3.425, 95\% CI: 2.961 3.962).

\section{대사증후군을 예측하기 위한 요산과 안정시 심박수의 절단값}

$\mathrm{ROC}$ 분석을 이용하여 대사증후군을 진단하기 위한 요 산과 안정시 심박수의 적정 절단값을 측정한 결과는 Table 4와 같으며, Fig. 1과 Fig. 2에서는 검사 항목별 ROC 곡선 을 나타냈다. 곡선의 아래 면적인 AUC (area under the ROC curve)는 분류 정확도를 나타내며, 전체 대상자에서 요산 의 AUC 값은 0.620 , 남성은 0.564 , 여성은 0.676 으로 나타 났다. 또한 대사증후군 진단을 위한 전체 대상자의 요산 절단값은 $4.95 \mathrm{mg} / \mathrm{dL}$, 민감도는 $73.0 \%$, 특이도는 $44.3 \%$ 로
나타났다. 여성 대상자의 경우 요산 절단값은 $4.55 \mathrm{mg} / \mathrm{dL}$, 민감도 $57.1 \%$, 특이도 $69.2 \%$, 남성 대상자는 요산 절단값 은 $6.35 \mathrm{mg} / \mathrm{dL}$, 민감도 $47.7 \%$, 특이도 $62.5 \%$ 로 나타났다. 전체 대상자에서 안정시 심박수의 $\mathrm{AUC}$ 값은 0.609 , 남성 0.615 , 여성 0.601 로 나타났다. 대사증후군 진단을 위한 전 체 대상자의 안정시 심박수 절단값은 분당 67.50 회에 민 감도는 $42.7 \%$, 특이도는 $73.0 \%$ 로 나타났다. 여성 대상자 의 경우 안정시 심박수 절단값은 분당 67.50 회에 민감도 는 $42.9 \%$, 특이도는 $72.6 \%$ 를 나타냈으며, 남성의 안정시 심박수 절단값은 분당 65.50 회에 민감도 $50.1 \%$, 특이도 $66.2 \%$ 를 보였다.

\section{고 찰}

본 연구결과 한국 성인에서 성별, 연령과는 독립적으로 혈청 요산치와 안정시 심박수가 높을수록 대사증후군 위 험도가 증가하는 것을 확인하였다. 또한 요산은 $4.95 \mathrm{mg} /$ 


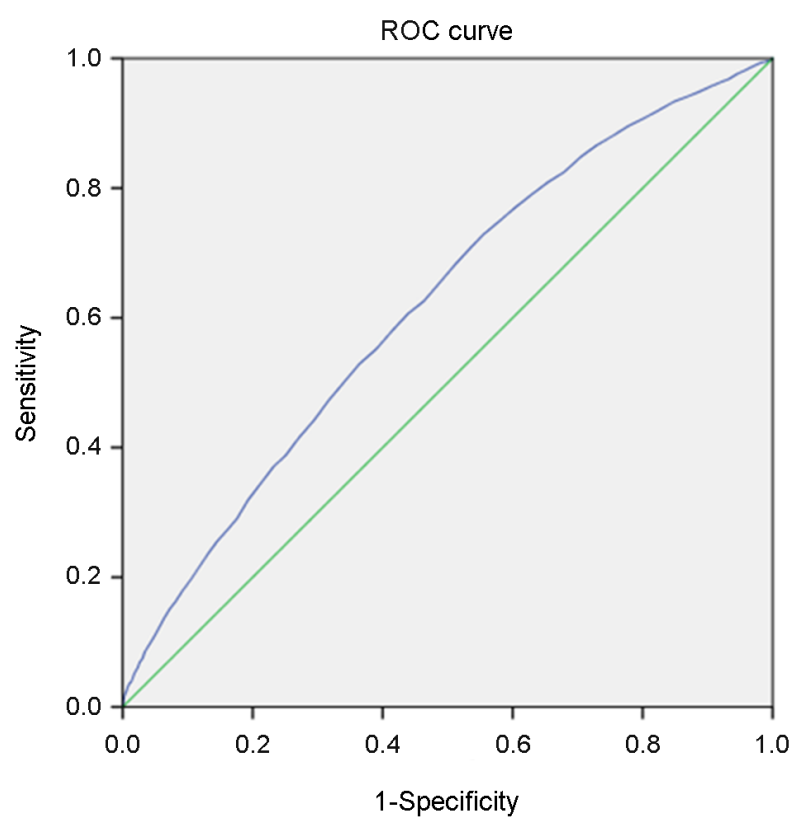

Fig. 1. ROC curve of uric acid for diagnosis of metabolic syndrome. $\mathrm{AUC}=0.620$, Cutoff value $=4.95 \mathrm{mg} / \mathrm{dL}$, Sensitivity $=$ $73.0 \%$, Specificity $=44.3 \%$

$\mathrm{dL}$, 안정시 심박수는 분당 68 회 이상일 때 대사증후군 위 험이 증가하는 것으로 나타났으며, 대사증후군을 진단하 는데 요산과 안정시 심박수의 $\mathrm{AUC}$ 값은 0.7 보다 낮은 정 확도를 보여 보조적인 지표로 이용하는 것이 타당할 것으 로 생각된다. 대사증후군은 내당능장애, 복부비만, 고혈압, 중성지방 증가와 $\mathrm{HDL}$-콜레스테롤 감소의 5 가지 진단기 준 중 3 가지 이상이 한 개인에게 군집화되어 나타나는 것 을 말하며, 복부비만과 인슐린저항성이 핵심 역할을 한다 고 알려져 있다(Eckel et al., 2010).

요산은 혈관 민무늬근육 증식을 자극하고 혈관내피세포 기능장애를 일으켜 산화질소의 생체 이용률을 억제하며, 결국 혈관 내 염증반응과 혈소판 응집 및 부착반응에 따 른 혈전 생성의 증가와 같은 동맥경화증에서 나타나는 혈 관 변화를 보인다(Kanellis and Kang, 2005; Choi and Park, 2015). 요산에 의한 혈관 확장기능과 혈관내피세포 기능의 저하는 인슐린저항성의 발생기전으로 인식되며(Tomiyama et al., 2011), 인슐린저항성은 콩팥에서의 요산배설 감소와 근위 세뇨관에서의 요산 재흡수에 의해 혈중 요산치 상승 을 유도한다(Feig et al., 2013; Li et al., 2013). Yoo 등(2004)은 혈중 요산 농도가 고혈압, 인슐린저항성 및 대사증후군 위험요인과 상관관계가 있으며, 정상범위의 혈청 요산 농

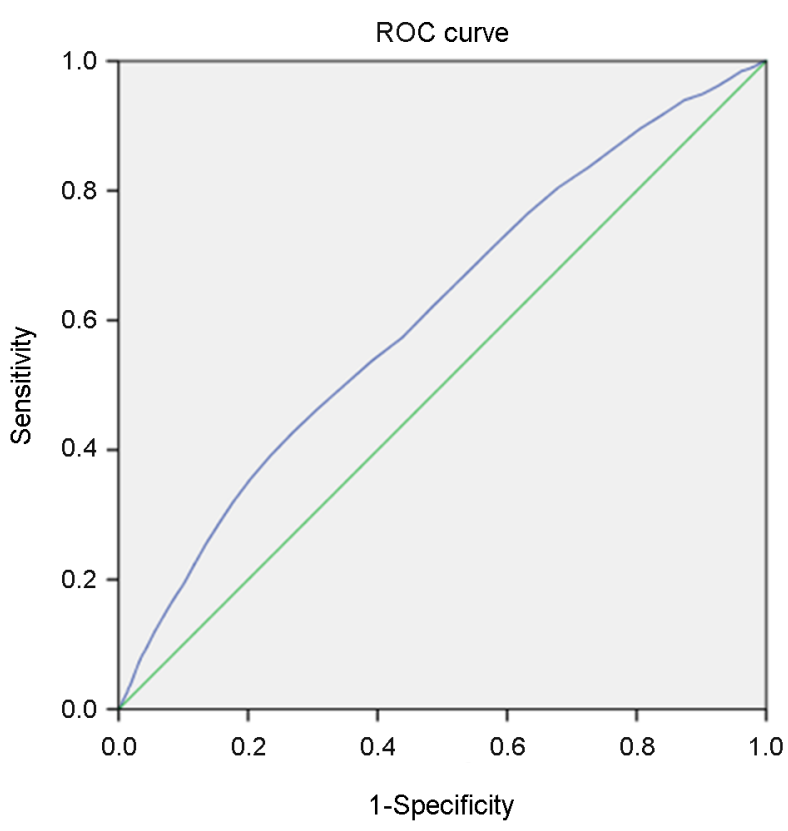

Fig. 2. ROC curve of resting heart rate for diagnosis of metabolic syndrome. $\mathrm{AUC}=0.609$, Cutoff value $=67.50 \mathrm{bpm}$, Sensitivity $=$ $42.7 \%$, Specificity $=73.0 \%$

도라 할지라도 혈청 요산 농도의 증가에 비례하여 대사 증후군 위험도가 증가한다고 보고하였다. 또한 여성 노인 을 대상으로 고요산혈증인 경우 대사증후군 발병 위험이 1.8 배 증가하였으며(Zhang et al., 2011), 50세 이상 남성을 대상으로 혈청 요산 농도를 3 분위로 나누어 5.7 년간 추적 관찰한 결과 요산 농도가 가장 낮은 군보다 가장 높은 군 의 대사증후군 발생이 1.8배 높았다(Sui et al., 2008).

본 연구결과 요산을 사분위수로 구분하였을 때 낮은 분위수에서 높은 분위수로 진행할수록 대사증후군 발생 위험이 높았으며, 1 사분위수보다 3 사분위수에서는 2.3 배, 4사분위수에서 대사증후군 발생 위험도가 3.4 배 높게 나 타났다. 또한 혈청 요산 농도의 상한치는 남성 $7.0 \mathrm{mg} / \mathrm{dL}$, 여성 $6.0 \mathrm{mg} / \mathrm{dL}$ 로 제시되며(Hong et al., 2008), 본 연구에서 대사증후군 위험이 증가하는 전체 대상자의 요산 적정 절 단값은 $4.95 \mathrm{mg} / \mathrm{dL}$ 였으며, 여성의 경우 $4.55 \mathrm{mg} / \mathrm{dL}$, 남성은 $6.35 \mathrm{mg} / \mathrm{dL}$ 로 성별과 연령에 따라 다양한 절단값을 적용 해야 할 필요성이 요구된다.

대사증후군에서는 교감신경계의 활성화로 안정시 심박 수가 증가하며, 대사증후군 위험요인의 개수가 증가함에 따라 안정시 심박수가 높게 나타나고 있어 심박수가 심혈 관질환의 위험을 예측할 수 있는 대사증후군 위험요인의 
하나로 간주된다(Shin, 2015). 실제로 8년간 3,527명을 대 상으로 안정시 심박수가 분당 90 회 이상인 대상자와 70 회 이하인 대상자를 비교한 결과 90 회 이상인 군의 심혈관계 질환에 의한 사망 위험이 2.2 배 높게 나타났으며, 심박수 가 높을수록 질환의 발병 가능성이 높고 경과도 좋지 않 음을 알 수 있었다(Kristal-Boneh et al., 2000).

본 연구결과 안정시 심박수를 사분위수로 구분하였을 때 낮은 분위수에서 높은 분위수로 진행할수록 대사증후 군 발생 위험이 높았으며, 1 사분위수보다 4 사분위수의 대 사증후군 발생 위험도는 3.4 배 높게 나타났다. 교감신경 과활성과 미주신경 긴장(vagal tone) 감소를 의미하는 심박 수 증가는 인슐린저항성과 관련이 있으며, 인슐린저항성 은 교감신경계와 레닌-안지오텐신 시스템을 활성화시킴 으로써 신세뇨관에서 나트륨 재흡수를 증가시켜 혈압과 심박수의 증가를 유발하게 된다(Reaven, 2002; Inoue et al., 2008; Nanchen et al., 2013). 심박수가 빠를수록 대사증후 군 위험은 높아지는데, 심근경색증 환자를 대상으로 베타 차단제로 심박수를 감소시킨 결과 사망률이 감소하는 것 으로 나타났다(Teo et al., 1993). 안정시 심박수는 분당 60 100 회로 정의하고 있으며(Jose and Collison, 1970), 본 연구 에서는 대사증후군 위험이 증가하는 안정시 심박수의 적 정 절단값은 분당 68 회로 나타났다. 한편, 선행연구에서 는 안정시 심박수가 분당 76회 이상일 경우 관상동맥질 환에 의한 사망 위험률이 높다고 제시하고 있어 심박수를 낮게 유지하는 것이 질환 발생을 예방하는데 바람직할 것 으로 사료된다(Hsia et al., 2009). 그러나 심박수는 연령 증가와 함께 낮아지는 것으로 알려져 있으며(Park et al., 2015), 연령대에 따라 적용 가능한 심박수의 절단값에 대 한 후속연구가 필요하겠다.

본 연구는 단면 연구로써 원인과 결과의 인과관계를 설 명할 수 없으며, 일개 종합병원 건강검진센터에서 건강검 진을 실시한 성인을 대상으로 하여 결과를 일반화하는데 제한이 있다. 또한 음주나 흡연, 운동 및 식이습관 등을 고려하지 못한 제한점이 있으나, 요산과 안정시 심박수가 대사증후군 진단에 유용한지를 최적 절단값 설정을 통해 알아본 대규모 연구로서 의미가 있다.

결론적으로 본 연구결과 한국 성인에서 요산치와 안정 시 심박수가 높을수록 대사증후군 위험도가 증가하는 것 으로 나타났다. 대사증후군 위험이 증가하는 요산의 최적 절단값은 $4.95 \mathrm{mg} / \mathrm{dL}$, 안정시 심박수의 최적 절단값은 분 당 68 회로 나타나, 정상범위라 할지라도 낮은 수치를 유 지하는 것이 바람직하겠다. 또한 요산과 안정시 심박수는
대사증후군을 예측하는데 독립적으로 사용하기에는 한계 가 있으나 보조적인 지표로는 사용 가능할 것으로 생각 된다.

\section{CONFLICT OF INTEREST}

The authors have no conflicts of interest to disclose.

\section{REFERENCES}

Bemelmans RH, Wassink AM, van der Graaf Y, Nathoe HM, Vernooij JW, Spiering W, Visseren FL; SMART Study Group. Risk of elevated resting heart rate on the development of type 2 diabetes in patients with clinically manifest vascular diseases. European Journal of Endocrinology. 2012. 166: 717-725.

Choi SY, Park JS. The comparison of carotid artery intima-media thickness and plaque characteristics between patients with ST-elevation myocardial infarction and coronary artery chronic total occlusion. Biomedical Science Letters. 2015. 21: 198 $-207$.

Diaz A, Bourassa MG, Guertin MC, Tardif JC. Long-term prognostic value of resting heart rate in patients with suspected or proven coronary artery disease. European Heart Journal. 2005. 26: 967-974.

Eckel RH, Alberti KG, Grundy SM, Zimmet PZ. The metabolic syndrome. Lancet. 2010. 375: 181-183.

Feig DI, Madero M, Jalal DI, Sanchez-Lozada LG, Johnson RJ. Uric acid and the origins of hypertension. Journal of Pediatrics. 2013. 162: 896-902.

Grundy SM, Cleeman JI, Daniels SR, Donato KA, Eckel RH, Franklin BA, Gordon DJ, Krauss RM, Savage PJ, Smith SC Jr, Spertus JA, Costa F; American Heart Association; National Heart, Lung, and Blood Institute. Diagnosis and management of the metabolic syndrome: an American Heart Association/ National Heart, Lung, and Blood Institute Scientific Statement. Circulation. 2005. 112: 2735-2752.

Hsia J, Larson JC, Ockene JK, Sarto GE, Allison MA, Hendrix SL, Robinson JG, LaCroix AZ, Manson JE; Women's Health Initiative Research Group. Resting heart rate as a low tech predictor of coronary events in women: prospective cohort study. British Medical Journal. 2009. 338: 219.

Hong SP, Lee YS, Bae KR, Chung JW, Kim SY, Lee JB, Ryu JK, Choi JY, Kim KS, Chang SG, Shin IH. Relationship between serum uric acid level and metabolic syndrome according to gender. Korean Circulation Journal. 2008. 38: 152-160. 
Inoue T, Iseki K, Iseki C, Ohya Y, Kinjo K, Takishita S. Association between heart rate and multiple risk factor syndrome: crosssectional analysis of a screened cohort in Okinawa, Japan. Circulation Journal. 2008. 72: 454-457.

Ioachimescu AG, Brennan DM, Hoar BM, Hazen SL, Hoogwerf BJ. Serum uric acid is an independent predictor of all-cause mortality in patients at high risk of cardiovascular disease: a preventive cardiology information system (PreCIS) database cohort study. Arthritis and Rheumatism. 2008. 58: 623-630.

Johansen CD, Olsen RH, Pedersen LR, Kumarathurai P, Mouridsen MR, Binici Z, Intzilakis T, Køber L, Sajadieh A. Resting, night-time, and $24 \mathrm{~h}$ heart rate as markers of cardiovascular risk in middle-aged and elderly men and women with no apparent heart disease. European Heart Journal. 2013. 34: 1732-1739.

Jose $\mathrm{AD}$, Collison $\mathrm{D}$. The normal range and determinants of the intrinsic heart rate in man. Cardiovascular Research. 1970. 4: 60-167.

Kanellis J, Kang DH. Uric acid as a mediator of endothelial dysfunction, inflammation, and vascular disease. Seminars in Nephrology. 2005. 25: 39-42.

Kristal-Boneh E, Silber H, Harari G, Froom P. The association of resting heart rate with cardiovascular, cancer and all-cause mortality. Eight year follow-up of 3527 male Israeli employees (the CORDIS Study). European Heart Journal. 2000. 21: 116 $-124$.

Lauer MS, Okin PM, Larson MG, Evans JC, Levy D. Impaired heart rate response to graded exercise. Prognostic implications of chronotropic incompetence in the Framingham Heart Study. Circulation. 1996. 93: 1520-1526.

Li C, Hsieh MC, Chang SJ. Metabolic syndrome, diabetes, and hyperuricemia. Current Opinion in Rheumatology. 2013. 25: 210-216.

Liu P, Jiang Y, Meng J. Relationship between serum uric acid, metabolic syndrome and resting heart rate in Chinese elderly. Obesity Research \& Clinical Practice. 2016. 10: 159-168.

Menown IB, Davies S, Gupta S, Kalra PR, Lang CC, Morley C, Padmanabhan S. Resting heart rate and outcomes in patients with cardiovascular disease: where do we currently stand? Cardiovascular Therapeutics. 2013. 31: 215-223.

Moon K, Sung SH, Chang YK, Park IK, Paek YM, Kim SG, Choi TI, Jin YW. The association between Apolipoprotein E genotype and lipid profiles in healthy woman workers. Journal of Preventive Medicine \& Public Health. 2010. 43: 213-221.

Nanchen D, Stott DJ, Gussekloo J, Mooijaart SP, Westendorp RG,
Jukema JW, Macfarlane PW, Cornuz J, Rodondi N, Buckley BM, Ford I, Sattar N, de Craen AJ; PROSPER Group. Resting heart rate and incident heart failure and cardiovascular mortality in older adults: role of inflammation and endothelial dysfunction: the PROSPER study. European Journal of Heart Failure. 2013. 15: 581-588.

Palatini P, Julius S. Elevated heart rate: a major risk factor for cardiovascular disease. Clinical and Experimental Hypertension. 2004. 26: 637-644.

Park H, Lee J, Kim JY, Kim DI, Jeon JY. The Relationship between resting heart rate and prevalence of metabolic syndrome and type 2 diabetes mellitus in Korean adults: The fifth Korea National Health and Nutrition Examination Survey (2012). Korean Journal of Obesity. 2015. 24: 166-174.

Reaven G. Metabolic syndrome: pathophysiology and implications for management of cardiovascular disease. Circulation. 2002. 106: 286-288.

Shin KA. Association between resting heart rate and risk factors of metabolic syndrome in Korean men. Journal of Wellness. 2015. 4: 305-316.

Sui X, Church TS, Meriwether RA, Lobelo F, Blair SN. Uric acid and the development of metabolic syndrome in women and men. Metabolism. 2008. 57: 845-852.

Tamariz L, Agarwal S, Soliman EZ, Chamberlain AM, Prineas R, Folsom AR, Ambrose M, Alonso A. Association of serum uric acid with incident atrial fibrillation. American Journal of Cardiology. 2011. 108: 1272-1276.

Teo KK, Yusuf S, Furberg CD. Effects of prophylactic antiarrhythmic drug therapy in acute myocardial infarction. An overview of results from randomized controlled trials. Journal of the American Medical Association. 1993. 270: 1589-1595.

Tomiyama H, Higashi Y, Takase B, Node K, Sata M, Inoue T, Ishibashi Y, Ueda S, Shimada K, Yamashina A. Relationships among hyperuricemia, metabolic syndrome, and endothelial function. American Journal of Hypertension. 2011. 24: 770 -774 .

World Health Organization Western Pacific Region, International Association for the Study of Obesity, and International Obesity Task Force. The Asian-Pacific perspective: redefining obesity and its treatment. Sydney, Australia. Health Communications Australia. 2000. 15-21.

Yoo TW, Sung KC, Kim YC, Hwang ST, Oh SY, Shin HS, Kim BJ, Kim BS, Kang JH, Lee MH, Park JR, Kim H, Lee KB, Lhee HY, Ryu SH, Keum DG. The relationship of the hypertension, insulin resistance, and metabolic syndrome in the 
serum uric acid level. Korean Circulation Journal. 2004. 34: 874-882.

Zhang Q, Lou S, Meng Z, Ren X. Gender and age impacts on the correlations between hyperuricemia and metabolic syndrome in Chinese. Clinical Rheumatology. 2011. 30: 777-787.
http://dx.doi.org/10.15616/BSL.2017.23.2.118

Cite this article as: Shin KA. Clinical Usefulness of Serum Uric Acid and Resting Heart Rate in the Diagnosis of Metabolic Syndrome in Korean Adults. Biomedical Science Letters. 2017. 23: 118-127. 